[Regular Paper]

\title{
Optimum Preparation Conditions for Alumina Catalyst Containing Cobalt for the Selective Catalytic Reduction of Nitrogen Monoxide with Ethene in Excess Oxygen
}

\author{
Noriyasu OKAZAKI*, Ryuta FuJII, and Akio TADA \\ Dept. of Applied and Environmental Chemistry, Kitami Institute of Technology, Kitami, Hokkaido 090-8507, JAPAN
}

(Received December 6, 2001)

\begin{abstract}
Alumina catalysts containing Co were prepared under various conditions of Co loading, Co salt and calcination temperature to elucidate the factors affecting the activity for the selective reduction of NO with ethene in excess oxygen, and the acctive Co species. The optimum calcination temperature was $800^{\circ} \mathrm{C}$ regardless the type of Co salt and the loading of $\mathrm{Co}$, at which formation of $\mathrm{CoAl}_{2} \mathrm{O}_{4}$ was maximum, formation of $\mathrm{Co}_{3} \mathrm{O}_{4}$ was minimum and the $\gamma$-type structure of alumina was retained. The catalytically active component is $\mathrm{CoAl}_{2} \mathrm{O}_{4}$, which acts as a cocatalyst with $\gamma$-alumina to complete the reduction of NO.
\end{abstract}

\section{Keywords}

Cobalt aluminate, Nitrogen monoxide, Catalyst preparation, Ethene, Selective catalytic reduction

\section{Introduction}

Selective catalytic reduction of nitrogen monoxide with hydrocarbons in excess oxygen (SCR-NO) has been investigated extensively as one of the most promising techniques for removing $\mathrm{NO}$ in exhaust gases $^{1)}$. Various catalysts including zeolites, metal oxides, and supported noble metals have been evaluated $^{1)}$. Alumina shows excellent activity for SCR-NO and its activity is enhanced by addition of transition metal elements ${ }^{2-11)}$, among which Co is one of the most effective elements. $\mathrm{CoAl}_{2} \mathrm{O}_{4}$ formed during calcination is the species involved in the SCR-NO ${ }^{3)}$. Therefore, it is important to know which variables in the preparation procedures affect the formation of $\mathrm{CoAl}_{2} \mathrm{O}_{4}$ for preparation of highly active catalysts for SCR-NO.

A typical preparation method for Co loaded alumina involves impregnation of alumina with an aqueous solution of cobalt salt followed by drying and calcining at $500-800^{\circ} \mathrm{C}$. The loading of Co is usually $0.1-5 \%$. The effects of Co loading, type of Co salt, and calcination temperature on the catalytic properties and type of Co species in the resulting catalyst were examined ${ }^{9)}$. Catalyst containing $0.1-0.5 \%$ Co prepared by adding cobalt acetate and calcining at $500^{\circ} \mathrm{C}$ showed the highest activity ${ }^{8}$. Excessive concentrations of surface cobalt ions decreased the activity, probably because of

* To whom correspondence should be addressed.

* E-mail: zaki@catal.chem.kitami-it.ac.jp the promotion of unfavorable side reactions such as the formation of NO. The optimum loading of Co after calcining at different temperatures has not been clarified. The Co species causing the unfavorable side reactions associated with excessive Co has not been identified.

Catalyst calcined at $800^{\circ} \mathrm{C}$ showed higher activity than catalyst calcined at $500^{\circ} \mathrm{C}^{3), 9)}$, for catalysts prepared with cobalt acetate and cobalt nitrate with a $\mathrm{Co}$ loading of $2 \%$. However, the optimum calcination temperature for catalysts containing different Co loadings, and for catalysts prepared from different cobalt salts has not been investigated. Changes in catalytic activity with calcination at temperatures higher than $800^{\circ} \mathrm{C}$ are also unknown.

Catalyst prepared from acetate and calcined at $600^{\circ} \mathrm{C}$ showed higher activity than catalyst prepared from nitrate and calcined at $500^{\circ} \mathrm{C}$. The activity of catalyst prepared from chloride has not been assessed.

In the present study, several $\mathrm{Co} /$ alumina catalysts were prepared using various Co loadings, Co salts, and calcination temperatures to elucidate how these variables affect the catalytic properties and the formation of Co species.

\section{Experimental Method}

\section{1. Preparation of Catalysts}

Alumina (ALOA) was prepared by hydrolyzing aluminum isopropoxide followed by washing with deion- 


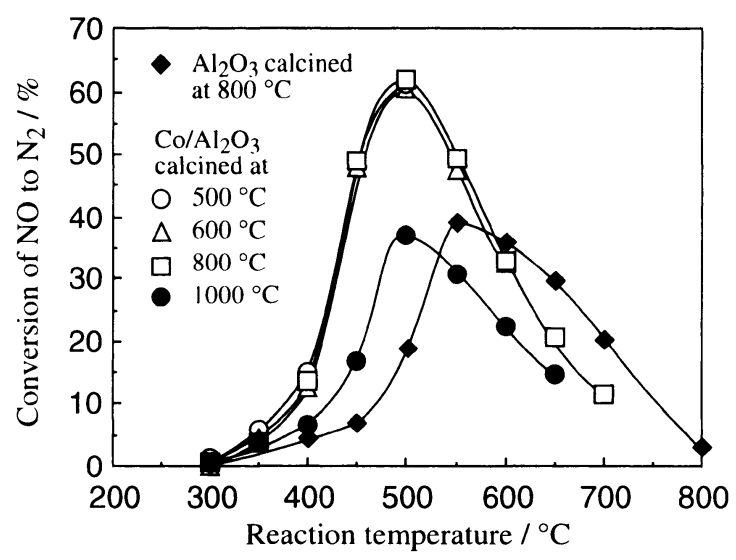

Fig. 1 Temperature Dependence of the Catalytic Activity of $\mathrm{Co}(0.2) / \mathrm{Al}_{2} \mathrm{O}_{3}$ Calcined at Various Temperatures

ized water, drying at $120^{\circ} \mathrm{C}$, and finally calcining at $600^{\circ} \mathrm{C}$ for $24 \mathrm{~h}$. $\mathrm{Co} / \mathrm{Al}_{2} \mathrm{O}_{3}$ catalysts were prepared by impregnation of the alumina with an aqueous solution of cobalt acetate tetrahydrate, cobalt nitrate hexahydrate, or cobalt chloride hexahydrate with appropriate concentrations. The solvent was removed at $50^{\circ} \mathrm{C}$ in a rotary evaporator under a water pump vacuum until the solid appeared dry, followed by drying at $120^{\circ} \mathrm{C}$ for 24 $\mathrm{h}$ and calcination at $500^{\circ} \mathrm{C}$ for $4 \mathrm{~h}$ in air. More detailed procedures were reported elsewhere. The catalyst powders were pressed into pellets, followed by crushing, sieving (30-42 mesh), and calcining at 500$1200^{\circ} \mathrm{C}$ for $4 \mathrm{~h}$ in air before use.

Cobalt oxide, $\mathrm{Co}_{3} \mathrm{O}_{4}$, was prepared by heating cobalt hydroxide at $500^{\circ} \mathrm{C}$ for $4 \mathrm{~h}$ and then at $800^{\circ} \mathrm{C}$ for $4 \mathrm{~h}$ in air. The cobalt hydroxide was prepared from an aqueous solution of cobalt nitrate by hydrolysis with $10 \%$ aqueous ammonia to a final $\mathrm{pH}$ of 7 . The precipitate was filtered, washed, and dried at $120^{\circ} \mathrm{C}$ for $18 \mathrm{~h}$.

\section{2. Characterization of Catalysts}

X-Ray powder diffraction patterns were observed with a Rigaku Denki RINT-12.00 using nickel filtered $\mathrm{Cu} K \alpha$ radiation. The specific surface areas of the catalysts was determined by the BET method. UV-VIS reflectance spectra were measured with a Hitachi U3200 spectrometer equipped with a $60 \mathrm{~mm}$ diameter integrating sphere (Hitachi, 130-0632). X-Ray photoelectron spectroscopy (XPS) was performed with a Rigaku Denki XPS-7000 spectrometer, using an $\mathrm{Al} K \alpha$ $\mathrm{X}$-ray source operated at $10 \mathrm{kV}$ and $30 \mathrm{~mA}$. The binding energies were corrected using the value of $285.0 \mathrm{eV}$ for the $\mathrm{C} 1 \mathrm{~s}$ level resulting from the contaminated carbon. The reproducibilities of the obtained values were within $\pm 0.2 \mathrm{eV}$.

\section{3. Reaction Procedures}

A fixed bed flow reactor was employed for the reduction of NO with ethene at a W/F of $0.18 \mathrm{~g} \cdot \mathrm{s} \cdot$ $\mathrm{cm}^{-3}$ (catalyst, $0.4 \mathrm{~g}$; total flow rate, $130 \mathrm{~cm}^{3} \cdot \mathrm{min}^{-1}$ ) at

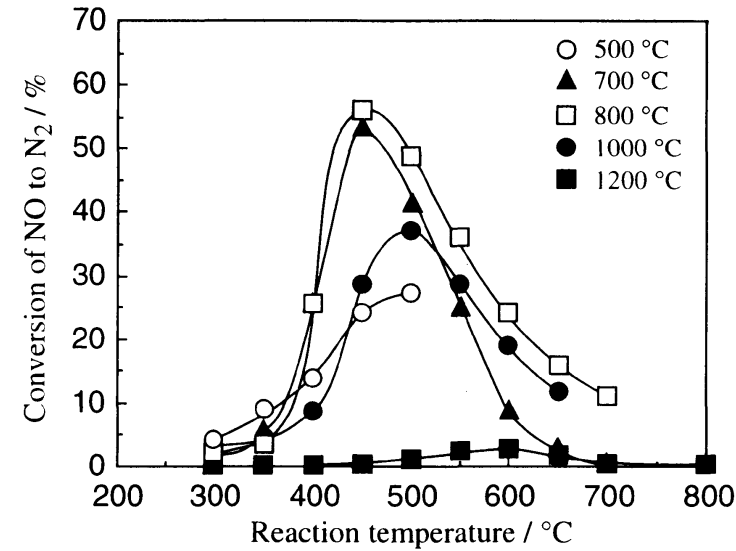

Fig. 2 Temperature Dependence of the Catalytic Activity of $\mathrm{Co}(5) / \mathrm{Al}_{2} \mathrm{O}_{3}$ Calcined at Various Temperatures

300 to $800^{\circ} \mathrm{C}$. The reactant gas (NO, $1000 \mathrm{ppm} ; \mathrm{O}_{2}$, $2.0 \% ; \mathrm{C}_{2} \mathrm{H}_{4}, 500 \mathrm{ppm} ; \mathrm{He}$, balance) was passed through the catalyst bed. The outflow gas was analyzed by gas chromatography using two columns packed with $5 \mathrm{~A}$ molecular sieves ( $3 \mathrm{~m}$; separation for $\mathrm{N}_{2}, \mathrm{O}_{2}, \mathrm{CO}$, and NO) and Porapak Q (3 m; separation for $\mathrm{CO}_{2}$, $\mathrm{C}_{2} \mathrm{H}_{4}$, and $\mathrm{N}_{2} \mathrm{O}$ ).

\section{Results}

The present study found that the catalytic activity for the reduction of NO with ethene in excess oxygen varied with the Co loading, calcination temperature, and the type of cobalt salt used to prepare the catalyst.

3. 1. Effects of Co Loading and Calcination Temperature on $\mathrm{Co} / \mathrm{Al}_{2} \mathrm{O}_{3}$ Prepared from Cobalt Acetate

Figure 1 shows the effect of the calcination temperature on the activity of Co/alumina, measured as conversion of $\mathrm{NO}$ to $\mathrm{N}_{2}$, prepared from cobalt acetate and containing $0.2 \mathrm{wt} \%$ Co. The activities are plotted against the reaction temperature for the catalysts calcined at different temperatures. As a reference, the activities of alumina calcined at $800^{\circ} \mathrm{C}$ and without addition of $\mathrm{Co}$ are also shown. The activity of Co/alumina containing $0.2 \mathrm{wt} \%$ Co was much higher than that of alumina without Co loading, and remained unchanged for calcination temperatures in the range $500-800^{\circ} \mathrm{C}$, but the activity decreased after calcination at $1000^{\circ} \mathrm{C}$.

Figure 2 shows the effect of the calcination temperature on the activity of Co/alumina containing $5 \mathrm{wt} \%$ Co. The activity of Co/alumina containing $5 \mathrm{wt} \% \mathrm{Co}$ was low after calcination at $500^{\circ} \mathrm{C}$, but the activity became higher at calcination temperatures in the range $700-800^{\circ} \mathrm{C}$, than decreased after calcination at $1000^{\circ} \mathrm{C}$ and was almost zero after calcination at $1200^{\circ} \mathrm{C}$.

The effect of the calcination temperature on the 


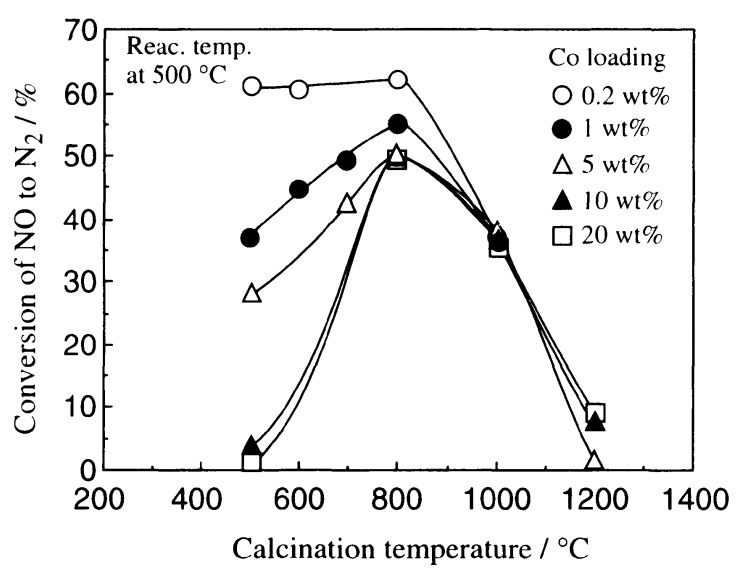

Fig. 3 Calcination Temperature Dependence of the Catalytic Activity of $\mathrm{Co} / \mathrm{Al}_{2} \mathrm{O}_{3}$

activity of Co/alumina containing $1 \mathrm{wt} \%$ Co was intermediate between those on Co/alumina containing 0.2 wt $\% \mathrm{Co}$ and Co/alumina containing $5 \mathrm{wt} \% \mathrm{Co}$. High activity for Co/alumina containing $20 \mathrm{wt} \%$ Co was obtained only after calcination at $800^{\circ} \mathrm{C}$, whereas activity was negligible after calcination at $500^{\circ} \mathrm{C}$.

Figure 3 shows the catalytic activity at a reaction temperature of $500^{\circ} \mathrm{C}$ as a function of the calcination temperature for $\mathrm{Co} /$ alumina catalyst containing different Co loadings. The activity depended strongly on the Co loading for calcination temperatures in the range $500-800^{\circ} \mathrm{C}$. The increase in activity with an increase in calcination temperature was greater for a larger Co loading. The maximum activities were obtained after calcination at $800^{\circ} \mathrm{C}$ for all catalysts. The activity decreased for all catalysts with calcination temperature above $800^{\circ} \mathrm{C}$.

\section{2. Effects of Co Loading and Calcination Tem- perature on $\mathrm{Co} / \mathrm{Al}_{2} \mathrm{O}_{3}$ Prepared from Cobalt Nitrate and Cobalt Chloride}

The effect of calcination temperature on the catalytic activity varied with the Co loading. Figure 4 shows the catalytic activity as a function of the reaction temperature for catalysts containing $0.2 \mathrm{wt} \%$ Co prepared from different cobalt salts and calcined at $500^{\circ} \mathrm{C}$ (Fig. 4 a)) and $800^{\circ} \mathrm{C}$ (Fig. 4 b)). Neither the calcination temperature nor the type of cobalt salt affected the activity of the catalysts containing $0.2 \mathrm{wt} \% \mathrm{Co}$.

Figure 5 shows the catalytic activity as a function of the reaction temperature for catalysts containing $5 \mathrm{wt} \%$ Co prepared from cobalt nitrate and cobalt chloride and calcined at $500^{\circ} \mathrm{C}$ and $800^{\circ} \mathrm{C}$. The catalysts prepared from cobalt nitrate and cobalt chloride by calcination at $500^{\circ} \mathrm{C}$ exhibited much lower activities than the catalyst containing $5 \mathrm{wt} \%$ Co prepared from cobalt acetate. However, the activities of these catalysts were remarkably increased by calcination at $800^{\circ} \mathrm{C}$ and the catalytic activities were essentially the same regardless of the

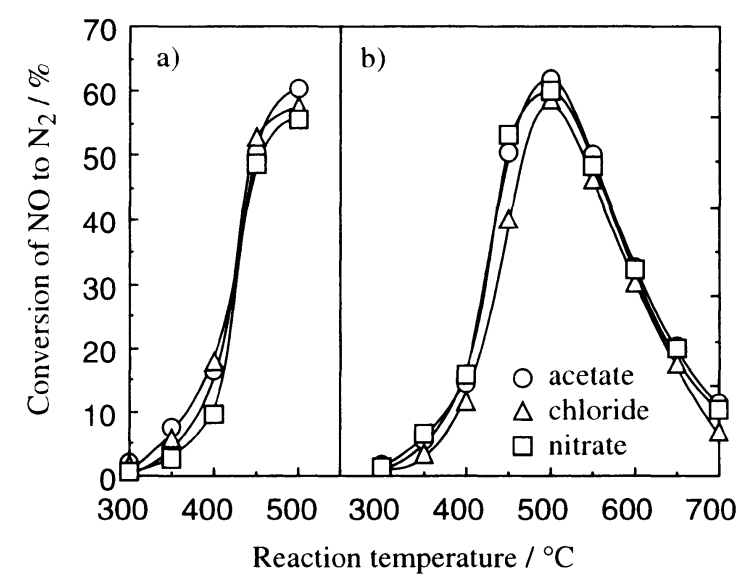

Fig. 4 Temperature Dependence of the Catalytic Activity of $\mathrm{Co}(0.2) / \mathrm{Al}_{2} \mathrm{O}_{3}$ Prepared from Various Co Salts and Calcined at a) $500^{\circ} \mathrm{C}$ and b) $800^{\circ} \mathrm{C}$

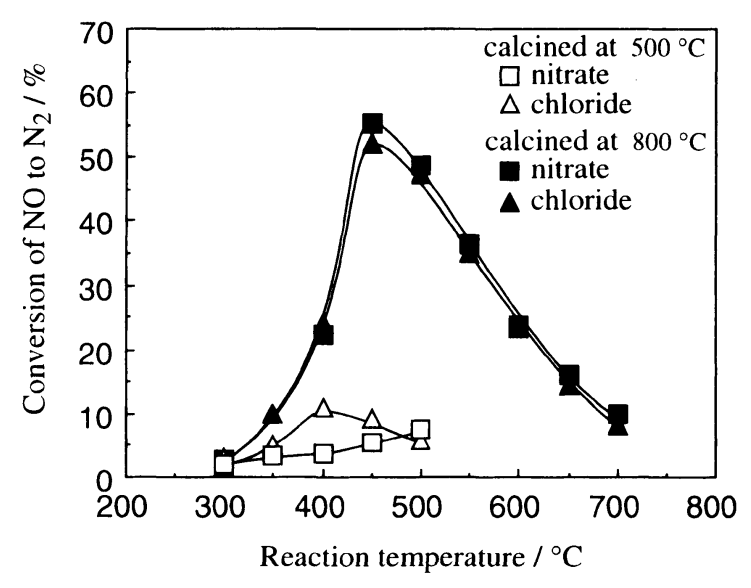

Fig. 5 Temperature Dependence of the Catalytic Activity of $\mathrm{Co}(5) / \mathrm{Al}_{2} \mathrm{O}_{3}$ Prepared from Various Co Salts

type of cobalt salt.

3. 3. Effects of Co Loading and Calcination Temperature on the Conversion of Ethene in the Selective Reduction of NO

Oxidation of ethene to $\mathrm{CO}_{x}$ also occurs in the reduction of NO with ethene in excess oxygen was also affected by the Co loading and the calcination temperature. Oxidation of ethene at lower temperature indicates lower catalytic activity for SCR-NO. Figures 6 a) and b) show the conversions of ethene to $\mathrm{CO}_{x}$ with reaction temperature for the catalysts prepared from cobalt acetate and calcined at $500^{\circ} \mathrm{C}$ and $800^{\circ} \mathrm{C}$, respectively. Conversion of ethene to $\mathrm{CO}_{x}$ occurred at lower temperatures for catalysts with higher Co loading calcined at $500^{\circ} \mathrm{C}$. However, the conversion of ethene to $\mathrm{CO}_{x}$ occurred at similar temperatures regardless of the Co loading for the catalysts calcined at $800^{\circ} \mathrm{C}$, and close to the temperature for the catalyst containing 0.2 wt $\%$ Co calcined at $500^{\circ} \mathrm{C}$. 


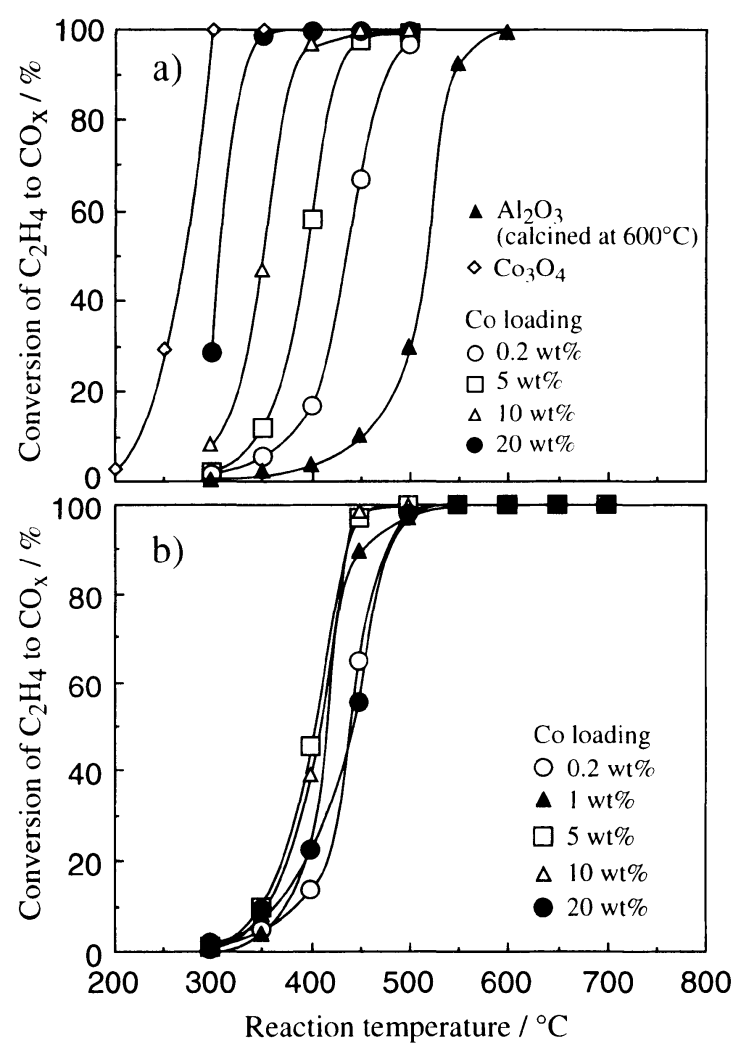

Fig. 6 Temperature Dependence of the Catalytic Activity of $\mathrm{Co} / \mathrm{Al}_{2} \mathrm{O}_{3}$ Calcined at a) $500^{\circ} \mathrm{C}$ and b) $800^{\circ} \mathrm{C}$

\section{4. Active Co Species on Alumina}

Figure 7 shows the UV-VIS spectra of the catalysts containing $5 \mathrm{wt} \%$ Co prepared from cobalt acetate and calcined at different temperatures together with the spectra of $\mathrm{Co}_{3} \mathrm{O}_{4}$ and $\mathrm{CoAl}_{2} \mathrm{O}_{4} . \mathrm{Co}_{3} \mathrm{O}_{4}$ has weak broad peaks at $380 \mathrm{~nm}$, and $650 \mathrm{~nm}$. $\mathrm{CoAl}_{2} \mathrm{O}_{4}$ has triple peaks in the range $500-650 \mathrm{~nm}$, and a broad shoulder in the range $300-400 \mathrm{~nm}$.

The catalyst calcined at $300^{\circ} \mathrm{C}$ had a spectrum similar to that of $\mathrm{Co}_{3} \mathrm{O}_{4}$, and showed no peaks characteristic of $\mathrm{CoAl}_{2} \mathrm{O}_{4}$. The peaks ascribed to $\mathrm{CoAl}_{2} \mathrm{O}_{4}$ began to appear at the calcination temperature of $500^{\circ} \mathrm{C}$, and became stronger at higher calcination temperatures. The triple peaks became maximum at the calcination temperature of $800^{\circ} \mathrm{C}$. The shoulder peak in the range $300-400 \mathrm{~nm}$ developed at calcination temperatures of $1200^{\circ} \mathrm{C}$ and $1400^{\circ} \mathrm{C}$. Clearly, $\mathrm{Co}_{3} \mathrm{O}_{4}$ was converted into $\mathrm{CoAl}_{2} \mathrm{O}_{4}$ by calcination, beginning at below $500^{\circ} \mathrm{C}$ and increasing until about $800^{\circ} \mathrm{C}$ at which temperature most $\mathrm{Co}_{3} \mathrm{O}_{4}$ was converted to $\mathrm{CoAl}_{2} \mathrm{O}_{4}$.

Figure 8 shows XPS spectra of the Co $2 p$ core level for the catalysts calcined at different temperatures. The deconvoluted curves resulting from computer peak fitting are also shown with the binding energies for $\mathrm{Co}_{3} \mathrm{O}_{4}$ and $\mathrm{CoAl}_{2} \mathrm{O}_{4}$. The peak intensity corresponding to $\mathrm{Co}_{3} \mathrm{O}_{4}$ was decreased by raising the calcination

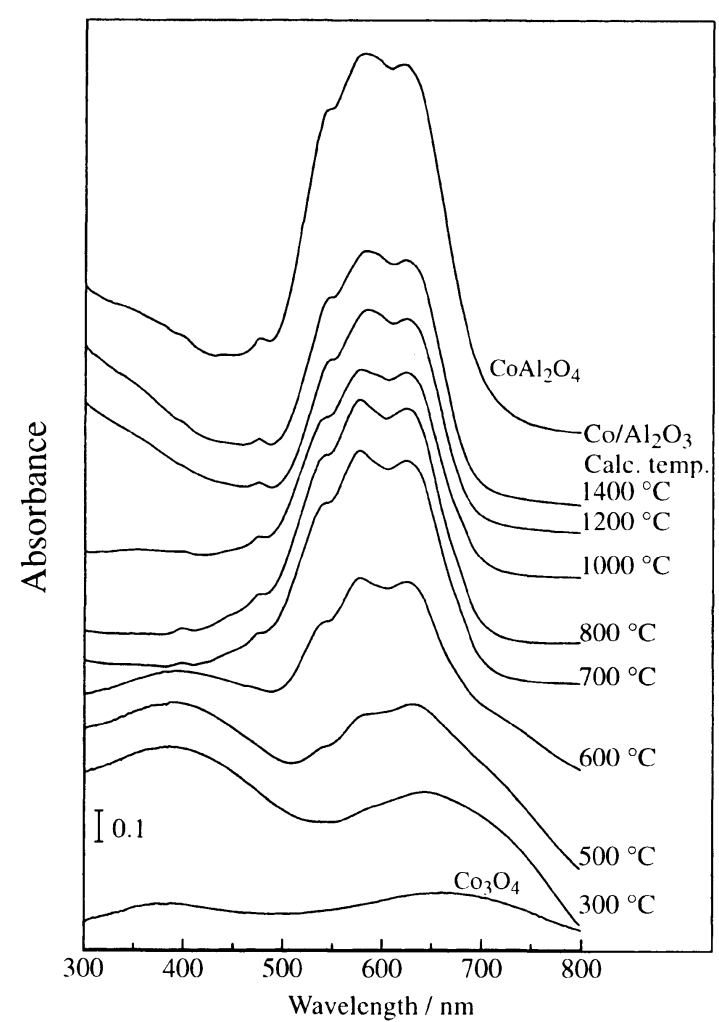

Fig. 7 Diffuse Reflectance Spectra of $\mathrm{Co}(\mathrm{A}, 5) / \mathrm{Al}_{2} \mathrm{O}_{3}$ Calcined at Various Temperatures

temperature from 500 to $800^{\circ} \mathrm{C}$, and the peak for $\mathrm{Co}_{3} \mathrm{O}_{4}$ was not detected after calcination at $1000^{\circ} \mathrm{C}$. The XPS findings also show that $\mathrm{Co}_{3} \mathrm{O}_{4}$ was converted to $\mathrm{CoAl}_{2} \mathrm{O}_{4}$ by calcination, and converted almost completely after calcination at $1000^{\circ} \mathrm{C}$ for the catalyst containing $5 \mathrm{wt} \%$ Co prepared from cobalt acetate.

The fractions of $\mathrm{Co}_{3} \mathrm{O}_{4}$ and $\mathrm{CoAl}_{2} \mathrm{O}_{4}$ after calcination at a certain temperature varied with the Co loading. Figure 8 shows the change in the fraction of $\mathrm{CoAl}_{2} \mathrm{O}_{4}$ of total $\mathrm{Co}$ species in $\mathrm{Co} /$ alumina calcined at $500^{\circ} \mathrm{C}$ and $800^{\circ} \mathrm{C}$ as a function of the Co loading. The fraction of $\mathrm{CoAl}_{2} \mathrm{O}_{4}$ markedly decreased with increased $\mathrm{Co}$ loading for $\mathrm{Co} /$ alumina calcined at $500^{\circ} \mathrm{C}$, to 0.92 for the catalyst containing $0.2 \mathrm{wt} \% \mathrm{Co}$, and 0.43 for the catalyst containing $20 \mathrm{wt} \% \mathrm{Co}$. In contrast, the fraction of $\mathrm{CoAl}_{2} \mathrm{O}_{4}$ did not decrease much with the Co loading for the catalysts calcined at $800^{\circ} \mathrm{C}$, exceeding 0.94 regardless of the Co loading. Figure 9 shows the changes in fraction of $\mathrm{CoAl}_{2} \mathrm{O}_{4}$ in the catalysts prepared from cobalt acetate and cobalt nitrate containing $5 \mathrm{wt} \% \mathrm{Co}$ as a function of the calcination temperature. The fraction of $\mathrm{CoAl}_{2} \mathrm{O}_{4}$ in the catalyst prepared from cobalt nitrate was only 0.35 , whereas that in the catalyst prepared from cobalt acetate exceeded 0.85 after calcination at $500^{\circ} \mathrm{C}$. In contrast, the fraction of $\mathrm{CoAl}_{2} \mathrm{O}_{4}$ was the same for both catalysts after calcination at $800^{\circ} \mathrm{C}$. Conversion of $\mathrm{Co}_{3} \mathrm{O}_{4}$ into $\mathrm{CoAl}_{2} \mathrm{O}_{4}$ is 


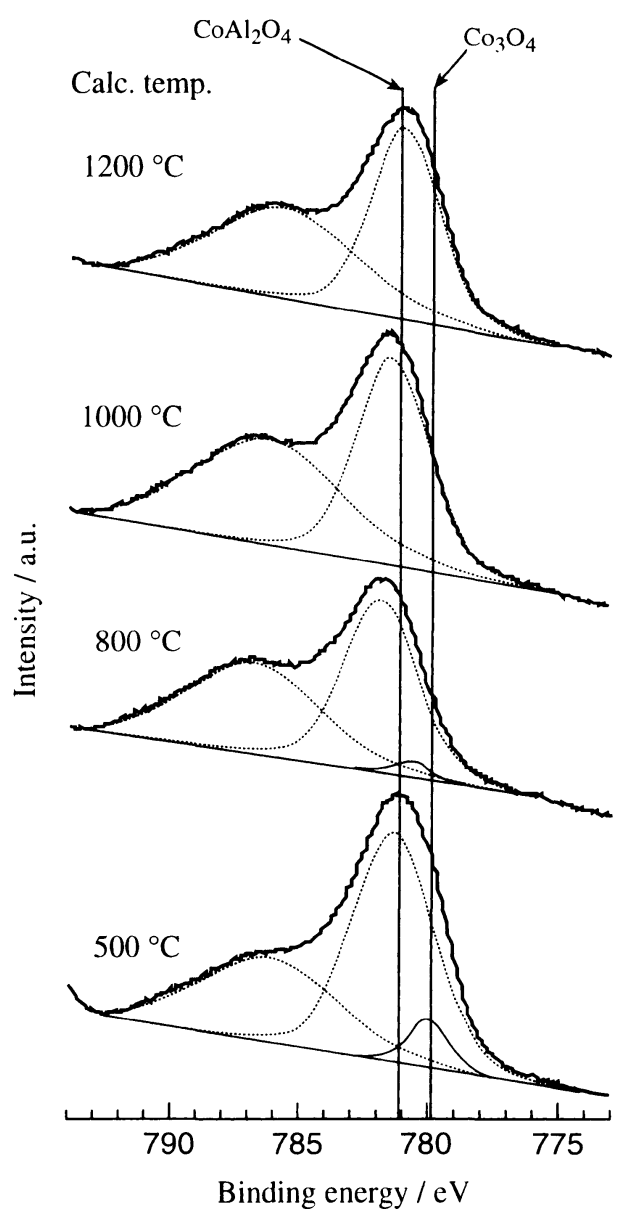

Fig. 8 Co $2 p_{3 / 2}$ XPS Spectra of $\mathrm{Co}(\mathrm{A}, 5) / \mathrm{Al}_{2} \mathrm{O}_{3}$ Calcined at Various Temperatures

greater for catalyst prepared from cobalt acetate than for catalyst prepared from cobalt nitrate. The conversion of $\mathrm{Co}_{3} \mathrm{O}_{4}$ or $\mathrm{CoCl}_{2}$ into $\mathrm{CoAl}_{2} \mathrm{O}_{4}$ could not be measured for the catalyst prepared from cobalt chloride because the peak of $\mathrm{CoCl}_{2}$ was superimposed on the peak of $\mathrm{CoAl}_{2} \mathrm{O}_{4}$.

Table 1 lists the crystal phases of the various catalysts together with the surface areas. The surface area gradually decreased with higher calcination temperature regardless of the Co loading and Co source. A substantial decrease was observed after calcination at $1000^{\circ} \mathrm{C}$ and $1200^{\circ} \mathrm{C}$. The surface area also decreased for the catalyst containing $20 \mathrm{wt} \%$ Co.

The crystalline structure of alumina was the $\gamma$-type after calcination up to $800^{\circ} \mathrm{C}$. $\alpha$-Alumina was present with $\gamma$-alumina after calcination at $1000^{\circ} \mathrm{C}$, and only $\alpha$ alumina was present after calcination at $1200^{\circ} \mathrm{C}$.

Only $\mathrm{Co}_{3} \mathrm{O}_{4}$ was found after calcination up to $500^{\circ} \mathrm{C}$ for the catalysts prepared from cobalt acetate and cobalt nitrate, and only $\mathrm{CoCl}_{2}$ after calcination at $500^{\circ} \mathrm{C}$ for the catalyst prepared from cobalt chloride. However, only $\mathrm{CoAl}_{2} \mathrm{O}_{4}$ was present regardless of the source of

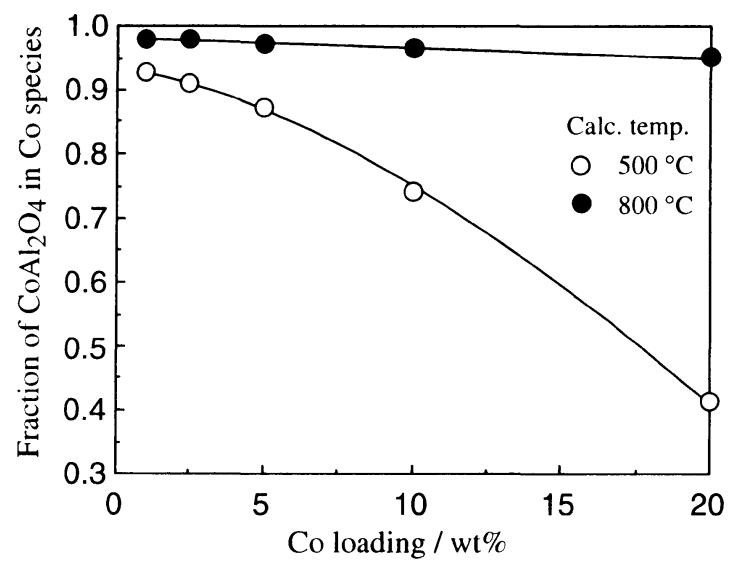

Fig. 9 Fraction of $\mathrm{CoAl}_{2} \mathrm{O}_{4}$ in $\mathrm{Co}$ Species $\left(\mathrm{CoAl}_{2} \mathrm{O}_{4}\right.$ and $\left.\mathrm{Co}_{3} \mathrm{O}_{4}\right)$ of $\mathrm{Co}(\mathrm{A}) / \mathrm{Al}_{2} \mathrm{O}_{3}$ as a Function of Cobalt Loading

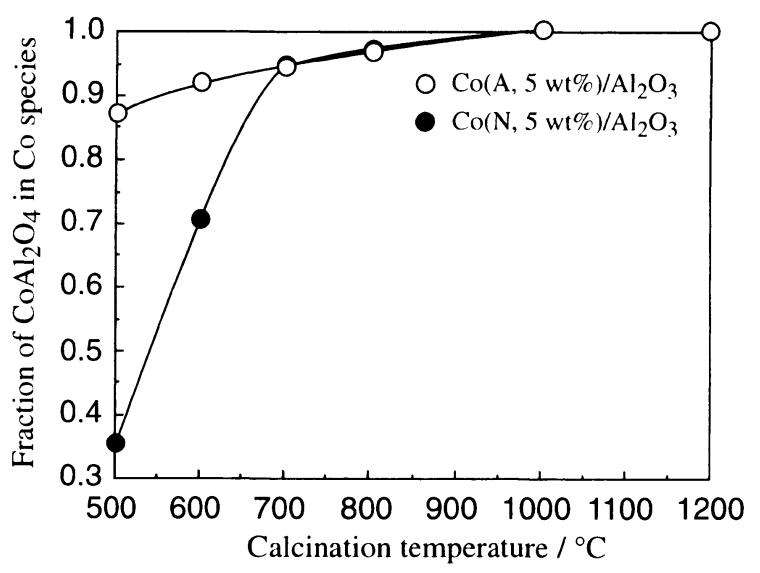

Fig. 10 Fraction of $\mathrm{CoAl}_{2} \mathrm{O}_{4}$ in Co Species $\left(\mathrm{CoAl}_{2} \mathrm{O}_{4}\right.$ and $\mathrm{Co}_{3} \mathrm{O}_{4}$ ) of $\mathrm{Co} / \mathrm{Al}_{2} \mathrm{O}_{3}$ as a Function of Calcination Temperature

cobalt after calcination at 800,1000 and $1200^{\circ} \mathrm{C}$.

\section{Discussion}

The results of the present study suggest that $\mathrm{CoAl}_{2} \mathrm{O}_{4}$ is the Co-species involved in the catalytic activity for the reduction of $\mathrm{NO}$ with ethene $\mathrm{e}^{3), 11}$. The formation of $\mathrm{CoAl}_{2} \mathrm{O}_{4}$ on alumina is affected by the loading of $\mathrm{Co}$, the calcination temperature, and the source of Co. The Co/alumina catalyst can be prepared to maximize the fraction of $\mathrm{CoAl}_{2} \mathrm{O}_{4}$ among the total Co species.

Reduction of NO with hydrocarbons in excess oxygen proceeds by the successive steps of (1) $\mathrm{NO}+1 / 2$ $\mathrm{O}_{2} \rightarrow \mathrm{NO}_{2}$ and (2) $\mathrm{NO}_{2}+\mathrm{HC} \rightarrow \mathrm{N}_{2}+\mathrm{CO}_{x}+\mathrm{H}_{2} \mathrm{O}$. The reaction (3) $\mathrm{HC}+\mathrm{O}_{2} \rightarrow \mathrm{CO}_{x}+\mathrm{H}_{2} \mathrm{O}$ also occurs, but is not desirable because ethene is unproductively consumed. $\mathrm{CoAl}_{2} \mathrm{O}_{4}$ actively catalyzes reaction (1), but not reaction (3) ${ }^{13)}$, whereas $\mathrm{Co}_{3} \mathrm{O}_{4}$ actively catalyzes 
Table 1 Surface Area and X-Ray Diffraction Patterns of $\mathrm{Co} / \mathrm{Al}_{2} \mathrm{O}_{3}$ Catalysts

\begin{tabular}{|c|c|c|c|c|}
\hline $\begin{array}{c}\text { Co loading } \\
{[\%]}\end{array}$ & Co source & $\begin{array}{c}\text { Calc. temp } \\
{\left[{ }^{\circ} \mathrm{C}\right]}\end{array}$ & $\begin{array}{c}\text { Surface area } \\
{\left[\mathrm{m}^{2} \cdot \mathrm{g}^{-1}\right]}\end{array}$ & $X$-ray diffraction patterns \\
\hline 5 & acetate & 300 & 195 & $\gamma-\mathrm{Al}_{2} \mathrm{O}_{3}, \mathrm{Co}_{3} \mathrm{O}_{4}$ \\
\hline 5 & acetate & 500 & 180 & $\gamma-\mathrm{Al}_{2} \mathrm{O}_{3}, \mathrm{Co}_{3} \mathrm{O}_{4}$ \\
\hline 5 & acetate & 600 & 166 & $\gamma-\mathrm{Al}_{2} \mathrm{O}_{3}, \mathrm{Co}_{3} \mathrm{O}_{4}, \mathrm{CoAl}_{2} \mathrm{O}_{4}$ \\
\hline 5 & acetate & 700 & 156 & $\gamma-\mathrm{Al}_{2} \mathrm{O}_{3}, \mathrm{CoAl}_{2} \mathrm{O}_{4}$ \\
\hline 5 & acetate & 800 & 138 & $\gamma-\mathrm{Al}_{2} \mathrm{O}_{3}, \mathrm{CoAl}_{2} \mathrm{O}_{4}$ \\
\hline 5 & acetate & 1000 & 69 & $\gamma-\mathrm{Al}_{2} \mathrm{O}_{3}, \alpha-\mathrm{Al}_{2} \mathrm{O}_{3}, \mathrm{CoAl}_{2} \mathrm{O}_{4}$ \\
\hline 5 & acetate & 1200 & 4 & $\alpha-\mathrm{Al}_{2} \mathrm{O}_{3}, \mathrm{CoAl}_{2} \mathrm{O}_{4}$ \\
\hline 5 & nitrate & 500 & 209 & $\gamma-\mathrm{Al}_{2} \mathrm{O}_{3}, \mathrm{Co}_{3} \mathrm{O}_{4}$ \\
\hline 5 & nitrate & 800 & 120 & $\gamma-\mathrm{Al}_{2} \mathrm{O}_{3}, \mathrm{CoAl}_{2} \mathrm{O}_{4}$ \\
\hline 5 & chloride & 500 & 164 & $\gamma-\mathrm{Al}_{2} \mathrm{O}_{3}, \mathrm{CoCl}_{2}$ \\
\hline 5 & chloride & 800 & 129 & $\gamma-\mathrm{Al}_{2} \mathrm{O}_{3}, \mathrm{CoAl}_{2} \mathrm{O}_{4}$ \\
\hline 0.2 & acetate & 500 & 195 & - \\
\hline 1 & acetate & 500 & 192 & - \\
\hline 2.5 & acetate & 500 & 189 & - \\
\hline 0.2 & acetate & 800 & 144 & - \\
\hline 1 & acetate & 800 & 143 & - \\
\hline 2.5 & acetate & 800 & 141 & - \\
\hline 20 & acetate & 800 & 109 & $\gamma-\mathrm{Al}_{2} \mathrm{O}_{3}, \mathrm{CoAl}_{2} \mathrm{O}_{4}$ \\
\hline
\end{tabular}

reaction (3) ${ }^{12), 13)}$. Therefore, the $\mathrm{CoAl}_{2} \mathrm{O}_{4}$ species are essential to the reduction of NO with ethene in excess oxygen as controlled by reaction (1).

The fraction of $\mathrm{CoAl}_{2} \mathrm{O}_{4}$ was high in catalysts with low Co loading even after calcination at low temperature. Co/alumina catalyst containing $0.2 \mathrm{wt} \%$ Co included 0.92 of $\mathrm{Co}$ species as $\mathrm{CoAl}_{2} \mathrm{O}_{4}$ after calcination at $500^{\circ} \mathrm{C}$, and 0.98 as $\mathrm{CoAl}_{2} \mathrm{O}_{4}$ after calcination at $800^{\circ} \mathrm{C}$. Therefore, the optimum calcination temperature range is wide for $\mathrm{Co} /$ alumina containing $0.2 \mathrm{wt} \%$ Co.

In contrast, the fraction of $\mathrm{CoAl}_{2} \mathrm{O}_{4}$ was low in catalysts with high Co loading after calcination at low temperature, and a large fraction of Co species remained as $\mathrm{Co}_{3} \mathrm{O}_{4}$. Co/alumina catalyst containing $20 \mathrm{wt} \%$ Co included only 0.42 of Co species as $\mathrm{CoAl}_{2} \mathrm{O}_{4}$ after calcination at $500^{\circ} \mathrm{C}$, which increased to 0.95 after calcination at $800^{\circ} \mathrm{C}$. Therefore, the optimum calcination temperature range was narrow for the Co/alumina containing $20 \mathrm{wt} \%$ Co. Co/alumina catalysts containing between $0.2 \mathrm{wt} \%$ Co and $20 \mathrm{wt} \%$ Co showed intermediate relationships between the catalytic activity and the calcination temperature.

Conversion of $\mathrm{CO}_{3} \mathrm{O}_{4}$ into $\mathrm{CoAl}_{2} \mathrm{O}_{4}$ is affected not only by the Co loading but also by the type of Co salt used as the Co source. Calcination temperature and the type of Co salt had little effect for the Co/alumina catalysts containing $0.2 \mathrm{wt} \% \mathrm{Co}$, but much greater effects for the catalysts containing a larger amount of Co. Catalysts containing $5 \mathrm{wt} \% \mathrm{Co}$ and calcined at $500^{\circ} \mathrm{C}$ showed catalytic activities in the order: $\mathrm{Co} / \mathrm{alu}$ mina prepared from cobalt acetate $>\mathrm{Co} /$ alumina prepared from $\mathrm{CoCl}_{2}>\mathrm{Co} /$ alumina prepared from $\mathrm{Co}\left(\mathrm{NO}_{3}\right)_{2}$. The fraction of $\mathrm{CoAl}_{2} \mathrm{O}_{4}$ was larger for the catalyst prepared from $\mathrm{Co}$ acetate than for the catalyst prepared from $\mathrm{Co}\left(\mathrm{NO}_{3}\right)_{2}$. The Co species in the catalyst prepared from $\mathrm{CoCl}_{2}$ were mostly in the form of $\mathrm{CoCl}_{2}$. By raising the calcination temperature, the catalytic activities of the $\mathrm{Co} /$ alumina catalysts prepared from different Co salts became the same, indicating that most $\mathrm{Co}$ species were converted into $\mathrm{CoAl}_{2} \mathrm{O}_{4}$ by calcination at $800^{\circ} \mathrm{C}$ regardless of the Co salt.

The relationships between the Co loading, calcination temperature, and catalytic activity were evaluated by measuring the ethene conversion. Catalysts with high Co loading and low calcination temperature converted ethene by SCR-NO at low temperatures. In contrast, catalysts with high Co loading and low calcination temperature, converted ethene by reaction with oxygen and not with $\mathrm{NO}$ due to the considerable remaining $\mathrm{Co}_{3} \mathrm{O}_{4}$. By raising the calcination temperature to $800^{\circ} \mathrm{C}, \mathrm{Co}_{3} \mathrm{O}_{4}$ was converted into $\mathrm{CoAl}_{2} \mathrm{O}_{4}$ and the catalyst showed a high activity for SCR-NO.

The fraction of $\mathrm{CoAl}_{2} \mathrm{O}_{4}$ increases with calcination temperatures exceeding $800^{\circ} \mathrm{C}$ as shown by UV spectroscopy and XPS. However, the catalytic activity decreases as the calcination temperature exceeds $800^{\circ} \mathrm{C}$, because $\alpha$-alumina begins to appear. Only the $\alpha$-alumina phase is detected by XRD after calcination at $1200^{\circ} \mathrm{C}$, and the catalytic activity becomes negligibly small. Therefore, $\gamma$-alumina is required for catalytic activity for the reduction of $\mathrm{NO}$. $\mathrm{CoAl}_{2} \mathrm{O}_{4}$ promotes the oxidation of $\mathrm{NO}$ to $\mathrm{NO}_{2}$ (reaction (1)), and $\gamma$-alumina promotes the reaction of $\mathrm{NO}_{2}$ with ethene to $\mathrm{N}_{2}$ (reaction (2)). Regardless of the Co loading and the type of Co salt, the highest catalytic activity was obtained by calcination at $800^{\circ} \mathrm{C}$, at which the fraction of $\mathrm{CoAl}_{2} \mathrm{O}_{4}$ was sufficiently high, the fraction of $\mathrm{Co}_{3} \mathrm{O}_{4}$ remained negligibly small, and the $\gamma$-type alumina was retained. However, the possibility that the low activi- 
ty of the catalyst calcined at $1200^{\circ} \mathrm{C}$ was simply caused by a decrease in surface area cannot be excluded.

\section{Conclusions}

The formation of $\mathrm{CoAl}_{2} \mathrm{O}_{4}$ as the active species in the catalyst is affected by the Co loading, type of Co salt, and calcination temperature.

(1) The optimum Co loading varies with the calcination temperature. At a low calcination temperature of $500^{\circ} \mathrm{C}, 0.2 \mathrm{wt} \%$ Co provided the highest activity. At a calcination temperature of $800^{\circ} \mathrm{C}$, all catalysts containing Co in the range $0.2-20 \mathrm{wt} \%$ had high activities.

(2) The optimum calcination temperature varies with the Co loading. The optimum calcination temperature range for low loading is wide; catalyst loaded with 0.2 wt $\%$ Co had high activities in the calcination temperature range $500-800^{\circ} \mathrm{C}$ whereas catalyst loaded with 20 wt $\%$ Co had high activity only after calcination at $800^{\circ} \mathrm{C}$.

(3) The optimum calcination temperature range varies with the type of cobalt salt. The activity depended strongly on the calcination temperature for the catalysts prepared from cobalt nitrate and cobalt chloride but weakly for those prepared from cobalt acetate. All catalysts prepared from different cobalt salts showed the highest activity after calcination at $800^{\circ} \mathrm{C}$.
(4) $\gamma$-Alumina is probably essential for an active catalyst; as $\gamma$-alumina promotes the reaction of $\mathrm{NO}_{2}$ with ethene to form $\mathrm{N}_{2}$.

\section{References}

1) Iwamoto, M., Yahiro, H., Catal. Today, 22, 5 (1994).

2) Torikai, Y., Yahiro, H., Mizuno, N., Iwamoto, M., Catal. Lett., 9, 91 (1991).

3) Hamada, H., Kintaichi, Y., Sasaki, M., Ito, T., Tabata, M., Appl. Catal., 75, L1 (1991).

4) Sasaki, M., Hamada, H., Kintaichi, Y., Ito, T., Catal. Lett., 15, 297 (1992).

5) Miyadera, T., Appl. Catal. B: Environmental, 2, 199 (1993).

6) Miyadera, T., Yoshida, K., Chem. Lett., 1993, 1483.

7) Ukisu, Y., Sato, S., Muramatsu, G., Yoshida, K., Catal. Lett., 16, 11 (1992).

8) Hamada, H., Kintaichi, Y., Inaba, M., Tabata, M., Yoshinari, T., Tsuchida, H., Catal. Today, 29, 53 (1996).

9) Hamada, H., Kintaichi, Y., Tabata, M., Sasaki, M., Ito, T., Sekiyu Gakkaishi (J. Jpn. Petrol. Inst.), 36, (3), 149 (1993).

10) Hamada, H., Haneda, M., Kakuta, N., Miura, H., Inami, K., Nanba, T., Hua, W. Q., Ueno, A., Ohfune, H., Udagawa, Y., Chem. Lett., 1997, 887.

11) Nanba, T., Uemura, A., Ueno, A., Haneda, M., Hamada, H., Kakuta, N., Miura, H., Ohfune, H., Udagawa, Y., Bull. Chem. Soc. Jpn., 71, (10), 2331 (1998).

12) Okazaki, N., Tsuda, S., Shiina, Y., Tada, A., Chem. Lett., 1998, 51.

13) Okazaki, N., Tsuda, S., Shiina, Y., Tada, A., Iwamoto, M., Chem. Lett., 1998, 429.

要 旨

\title{
酸素過剩雾囲気下におけるエチレンによる NO 選択還元反応 一コバルト添加アルミナ触媒の最適調製条件一
}

\author{
岡崎 文保, 藤井 竜太, 多田 旭男 \\ 北見工業大学化学システム工学科, 090-8507 北海道北見市公園町 165
}

\begin{abstract}
酸素過剩雲囲気下でエチレンを還元剤に用いた一酸化窒素の 選択還元反応において, 触媒活性に影響を及ぼす要因, および 活性に関わるコバルト種を明らかにするために，コバルト添加 量, コバルト出発塩の種類, および触媒焼成温度など, 調製条 件の異なるコバルト添加アルミナの触媒活性を詳細に検討し た。その結果, コバルト出発塩の種類とその添加量によらず最

適焼成温度は $800^{\circ} \mathrm{C}$ であること，この焼成温度ではアルミナが $\gamma$ 型の構造を保持したまま, アルミナ上でコバルトアルミネー トの生成が容易に進行し, 酸化コバルトの量が最小となること がわかった。これは $\gamma$-アルミナの NO 還元活性を向上させる 活性なコバルト種はコバルトアルミネートであることを示唆す る。
\end{abstract}

